\title{
A proposal for efficient rapid control of the Ebola hemorrhagic fever
}

\author{
Renan Marino \\ School of Medicine of São José do Rio Preto, Brazil
}

A major catastrophe hit Western Africa and we would like to put a definite end to that nightmare. Ever since in its initial identification in 1976, the Ebola virus is endemic in Zaire (currently, Democratic Republic of the Congo - DRC), where it has exerted devastating effects. For many years now, the virus has mercilessly attacked our fellow men, killing entire families overnight and leaving thousands of children orphan.

The current, being the seventh epidemic of Ebola hemorrhagic fever (EHF) in the RDC, also broke out in West Africa - Guinea, Liberia, Sierra Leone Nigeria and Senegal.

The World Health Organization (WHO) called specialists from several countries and concentrated efforts that might result in a practical contribution to the control of cases. It is worth to observe that the epidemic has caused more than 1,400 deaths in 2014 , being the fatality rate 60 to $90 \%$.

\section{Summary of the signs and symptoms of EHF}

$\mathrm{EHF}$ is an infectious and contagious disease caused by the Ebola virus, a RNA virus with filamentous appearance on electron microscopy, being its diameter about $80 \mathrm{~nm}$. Following a period of incubation of 1 to 3 weeks, the earliest symptoms of infection are similar to the ones of a common flu - fever, weakness, loss of appetite, headache, and muscle pain - which are insidiously followed by vomiting, diarrhea, bleeding, dehydration, shock, and death. The severity and speed of progression depend on the viral load, as well as on the nutritional status - and consequently, on the immune status - of patients.

Maculopapular rash appears in 50\% of the cases, being more intense on the chest and abdomen. The signs associated with the blood disorder appear by the end of the first week, including nausea and severe vomiting, hard-to-control epistaxis, hematemesis, melena, hemoptysis, conjunctival, skin, mucosal and gingival bleeding, and lip ulcers. Once this point is reached, disseminated intravascular coagulation (DIC) develops fast, leading to shock, multiple organ dysfunction and death.

There is no specific pharmacological treatment for EHF. Therapy is limited to fluid replacement, including blood, plasma or platelet transfusions, and use of vasopressors.

As a rule, diagnosis is established mainly on clinical-epidemiological grounds, being that certainty is achieved through the isolation of Ebola virus in cultures and identification of its serotypes, or by means of reverse transcription polymerase chain reaction (RT-PCR). 
The virus is mostly transmitted through direct contact with bodily fluids of affected individuals, including the urine, blood, sperm, sweat and saliva, as well as through fomites, like objects and clothes contaminated with the Ebola virus.

\section{Is there a relationship between EHF and mortality by the dengue hemorrhagic fever?}

This question should be answered with an unqualified yes. Here, I will elaborate on some specific features to provide a thorough understanding of the relationship between those two conditions. I discussed dengue, the dengue hemorrhagic fever (DHF) and epidemics at length in 2006, within my master dissertation, entitled "Homeopathy in collective health: a contribution to the study of epidemics, and defended at School of Medicine of Ribeirão Preto - Graduate Program in Health Science, São Paulo, Brazil.

My work actually started in 2001, when I formulated a program for population-based control of dengue epidemics in São José do Rio Preto, São Paulo, using homeopathic medicines[1]. In 2002, the WHO published its Traditional Medicine Strategy, which led the Brazilian Health Ministry (HM) to formulate a National Policy of Complementary and Integrative Practices (Política Nacional de Práticas Integrativas e Complementares - PNPIC; resolution HM/Minister Cabinet no. 971, June 3 2006), which regulates the use of homeopathy in epidemics. I interpreted those guidelines as both a source of encouragement and legal authorization to move forwards with the program and broadened its scope of action.

Based on the successful use of homeopathic medicines against dengue in São José do Rio Preto[2], and also in Macaé, Rio de Janeiro[3], in February and March 2007, the program was extended to cover thousands of individuals in different towns from various Brazilian states, including São Paulo, Rio de Janeiro, Minas Gerais, Espírito Santo and Goiás, in addition to Ciego de Ávila, Camaguey, and Havana, in Cuba.

Based on the results of clinical-epidemiological studies, in December 2008 the Brazilian Health Surveillance Agency (ANVISA) approved the abovementioned combination of homeopathic medicines for use in the treatment of dengue, which was registered by a Brazilian pharmaceutical company as Proden ${ }^{\circledR}$. That combination was one of the five candidates nominated for Sanofi-Aventis $1^{\text {st }}$ Award for Innovative Medical Services - New Paths in Public Health, in June 2009.

To seek ANVISA approval, the combination of homeopathic medicines was subjected to rigorous tests on mice, rats and rabbits at Laboratory of Drug Research, Federal University of Amapá, Brazil. The results showed that the drug combination induced an average increase in the platelet count from $200,000 / \mathrm{ml}$ to $600,000 / \mathrm{ml}$ in male rats (Appendix).

The protocol and technical guidelines elaborated by the Health Secretary of São José do Rio Preto were implemented in all the municipal Primary Care Units[2]. Thousands of doses of the homeopathic drug combination were administered, being that the local population exhibited significant adherence to the program. As a result, despite the severity of the dengue epidemic, only one death occurred, the suspected reason being intoxication by acetaminophen.

Routine clinical practice bears witness to the rapid improvement of the overall state of individuals affected by dengue, being corroborated by an equally fast increase of the platelet count.

\section{Elaboration of a protocol for EHF}

DHF and EHF exhibit several features in common, as "in the hemorrhagic fevers by the Ebola and Marburg viruses, necropsy demonstrates disseminated hemorrhage in the skin, mucous membranes and internal organs, as well as large areas of necrosis in the liver and kidneys"[4]. The pathophysiology of both conditions is characterized by the occurrence of severe coagulation disorders, which are determinant for the rapid 
progression into shock, multiple organ dysfunction and death. In addition, recent studies using electron microscopy showed that liver inflammation is an universal occurrence in dengue by any of the four viral serotypes[5].

The homeopathic drug combination formulated for dengue comprises Phosphorus, Crotalus horridus and Eupatorium perfoliatum. The former two were included with an eye to HDF, while the latter matches the typical symptoms of classic, uncomplicated dengue.

The original homeopathic pathogenetic trial (HPT) of Eup-per was conducted in 1846 by the North American Academy of Homeopathic Medicine Association. The plant, commonly known as boneset, is native from the East of the United States, and was used by the local Indians to treat the so-called "break-bone fever". In turn, the HPT of Phos was performed in Germany (Dresden and Leipzig) by Samuel Hahnemann, the founder of homeopathy. Phos represents the prototype agent for the treatment of hepatitis, as corroborated by studies that subjected animals to experimental hepatitis induced by carbon tetrachloride[6]. Finally, Crot-h, prepared from the North American rattlesnake, was studied by Constantine Hering in 1837. It represents one of the most effective agents against profuse, generalized and rapidly progressing hemorrhage.

Based on the facts described above, the wide experience already achieved, and the characteristic manifestations of the EHF outbreak, it is evident that Phos and Crot-h - to remind, drugs already tested and used in the treatment of liver dysfunction and bleeding, as in DHF, should be used in the drug association for EHF. The third component of the combination should be the agent that best matches the epidemic genus of EHF, which is Ipecacuanha, prepared from the Brazilian plant Carapichea ipecacuanha (Brot.) L. Andersson.

Ipeca was one of the 24 so-called polychrest medicines described by Hahnemann, and is one among the 60 most used homeopathic drugs[7]. According to Vijnovsky's description[8], it is the main agent to be used in acute conditions presenting with fever, nausea, profuse active or passive bleeding through any body opening, chest tightness, cold sweating and pale face; the blood has an intense red hue and exhibits little tendency to clot. Guermonprez has called the attention to the relationship between the isoquinoline alkaloids present in C. ipecacuanha, and some of the pathogenetic/curative symptoms of homeopathic medicine Ipeca, like reflex nausea and salivation, bloody diarrhea (gastrointestinal bleeding), bronchial hypersecretion attended by cough and bloody sputum (hemoptysis), severe headache, and rapid development of weakness, characterized by strong and fast loss of vitality, dehydration and shock[9].

To summarize, the homeopathic drug combination against EHF should contain Phos, Crot-h and Ipeca.

Use of drug associations has a long history in homeopathy [10]. Their efficacy is ensured when the classic criteria for their use are met, and the concordance among the general modalities that attend the pathophysiological actions triggered by each component alone, as verified in animal or human experiments, is observed so as to prevent the mutual antagonism and neutralization of the active principles of those drugs, but to allow for the mutual potentiation of their individual effects to manifest.

The key factor in the identification of the appropriate homeopathic drug for a given epidemic is the closeness of its pathogenetic symptoms with the profile of manifestation of the latter, as expressed by a large number of the affected individuals. That coincidence is known as "similarity" or "law of similitude", which is the backbone of homeopathy proper.

Once the most adequate drug to check an epidemic is established, its potency should be selected. In the case of $\mathrm{EHF}$, as a function to the severity and intensity of symptoms, the potency should be $15 \mathrm{x}$, i.e., the same that was used in the experimental studies on dengue conducted with animals and approved by ANVISA, as mentioned above. 


\section{Indication and regimen of use of the EHF drug combination}

It should be systematically borne in mind that in the case of EHF, homeopathic treatment should be only considered as an adjuvant to other therapeutic actions, including the use of antibiotics in the case of bacterial complications.

Phos 15x, Crot-h 15x and Ipeca 15x should be prepared in combination (also known as complex homeopathic medicine) in 20-ml flasks containing $30 \%$ alcohol.

1) Regimen for severe cases of EHF: 5 drops per oral route every 20 minutes until clinical stabilization, with monitoring of hemodynamic and laboratory parameters, like hematocrit, white cell and platelet count, etc.

2) Regimen for stable cases of EHF: 5 drops every 2 hours until clinical improvement, based on the assessment of the patient's overall state, hydration status, blood pressure, urine output, absence of bleeding, and laboratory parameters, as above.

3) Prophylactic use: 5 drops per oral route twice per day (morning and evening) for the duration of the period of epidemic risk.

Target population: all susceptible individuals at locations in which cases of EHF occur.

\section{References}

[1] Marino R, Jamal EM, Esteves Neto SH, Constantino A, Braguini VR. Emprego Profilático da Homeopatia em uma Epidemia de Dengue. Pesquisa Homeopática/Homeopatia Esplorado 2003;18(2):2-6. Trabalho apresentado também no $59^{\circ}$ Congresso Panamericano de Homeopatia - Havana/Cuba, em 2003, a partir da experiência no bairro Cristo Rei em São José do Rio Preto;

[2] Marino R. Homeopathy and Collective Health: The Case of Dengue Epidemics. Int J High Dilution Res [online]. 2008; $\quad 7(25)$ : 179-185. Available from: http://www.feg.unesp.br/ ojs/index.php/ijhdr/article/view/312/373;

[3] Nunes LAS. Contribution of homeopathy to the control of an outbreak of dengue in Macaé, Rio de Janeiro. Int J High Dilution Res [online]. 2008; 7(25): 186-192. Available from: http://www.feg.unesp.br/ ojs/index.php/ijhdr/article/view/315/374;

[4] Bogliolo L; Brasileiro Filho G. Patologia. 6. ed. Rio de Janeiro: Ed. Guanabara Koogan, 2.000;

[5] Migowski E. Uso de Antitérmicos em Doenças Infecciosas Virais. Encarte Abbott do Brasil, 2002;

[6] Encyclopédie Médico-Chirurgicale: vol II “Homeopathie” - Ed. Tecniques, Paris;1960-1968;

[7] Kossak-Romanach A. Homeopatia em 1000 Conceitos. São Paulo. Editora Elcid; 1984;

[8] Vijnovsky B. Tratado de Matéria Medica Homeopática, tomo II, Buenos Aires.Ed. Albatros, 1981;

[9] Guermonprez M. et al. Materia Medicale Homeopathique, $2^{\mathrm{a}}$ ed., Doin Editeurs, 1985, France; 
[10] Clerc, A. Die vereinfachte Medizin oder die Complexe Homoeopathie. Basel: H. Georg Verlagsbuchhandlung, 1892.

\section{Appendix}

Preclinical toxicology study of homeopathic complex medicine conducted with mice, rats and rabbits at laboratory of Drug research, Federal University of Amapá, Amapá, Brazil. $<$ http://www.feg.unesp.br/ ojs/index.php/ijhdr/article/view/755/732>

\section{(c)) BY-NC-ND Licensed to GIRI}

Support: authors declare that this study received no funding

Conflict of interest: authors declare there is no conflict of interest

Received: July 28 ${ }^{\text {th }}$, 2014; Revised: September 26 ${ }^{\text {th }}$, 2014; Published: September 30 ${ }^{\text {th }}, 2014$.

Correspondence author: Renan Marino, renanmarino@uol.com.br

How to cite this article: Marino R. A proposal for efficient rapid control of the Ebola hemorrhagic fever. Int J High Dilution Res [online]. 2014 [cited YYYY Month dd]; 13(48): 182-186. Available from: : http://www.feg.unesp.br/ ojs/index.php/ijhdr/article/view/755/731 